\title{
Gastronomia, Sustentabilidade e Turismo na Praia de Caçandoca, Ubatuba (São Paulo-Brasil)
}

\author{
Gastronomy, Sustainability and Tourism in Caçandoca of Ubatuba ( São Paulo-Brazil)
}

Gastronomia, Sustentabilidad y Turismo em la Caçandoca de Ubatuba (São Paulo-Brasil)

Ricardo Frota de Albuquerque Maranhão ${ }^{1}$

Marielys Siqueira Bueno ${ }^{2}$

\begin{abstract}
Resumo
A praia de Caçandoca, em Ubatuba, possui uma comunidade de pesca artesanal que é também remanescente de um quilombo. Desde a abertura de estradas acessando praias da região do litoral norte paulista, a partir dos anos de 1970, a comunidade sofreu inúmeras pressões da especulação imobiliária para seu despejo e mudança, pela beleza do local e seu possível aproveitamento turístico. Mas ela conseguiu o reconhecimento da propriedade territorial como terra de quilombo, e hoje busca manter sua identidade e sua cultura material. Uma parte importante dessa cultura é sua culinária de pescados, levantada pelo A. em entrevistas abertas com antigos moradores da Caçandoca. E hoje, projetos comunitários e de governo oferecem possibilidades alternativas de aproveitamento dessa cozinha tradicional em uma atividade de turismo sustentável.
\end{abstract}

Palavras-chave: turismo sustentável; pesca artesanal; quilombo; culinária caiçara; UbatubaSP.

\begin{abstract}
The beach named Caçandoca, in Ubatuba, has an artisan fishing's community who is also remainder of a "quilombo". Since the opening of roads allowed access to the north coastland of São Paulo, on the seventies, the community have suffered a lot of pressures from the immovable speculation for her evacuation or removing, because of the natural beauty of the

\footnotetext{
${ }^{1}$ Doutor em História e Mestre em Ciências Sociais pela Universidade de São Paulo. Historiador e cientista político com pós-doutorado na Université de Montreal, Canadá. Professor doutor da Universidade Anhembi Morumbi na Graduação em Gastronomia e no Mestrado em Hospitalidade, e coordenador do Centro de Pesquisas em Gastronomia Brasileira dessa universidade. E-mail: almalmaranhaz@terra.com.br.

${ }^{2}$ Doutora em Sociologia pela Universidade de São Paulo e Mestre em Antropologia pela Universidade Federal de Goiás. Diploma de Estudos Aprofundados em Antropologia Social na Université René Descartes - Paris V e em Estudos Aprofundados em Ci. Diplôme de Études Approfondies en Cinéma Antropolológico na Unversité Nanterre - Paris X, França. Professora doutora da graduação em Gastronomia e do Mestrado em Hospitalidade da Universidade Anhembi Morumbi. E-mail: marielysbueno@gmail.com.
} 
place and its possible touristic utilization. But she obtained the recognition of the territory's property, as a "quilombo's" land, and nowadays she searchs to conserve her identity and her material culture. An important part of this culture is her fishing cookery, approached by the A. in opening interviews with old dwellers of Caçandoca. And, at the present time, community's and governmental's projects offer alternative possibilitys to make good use of this traditional cookery in a sustainable tourism acivity.

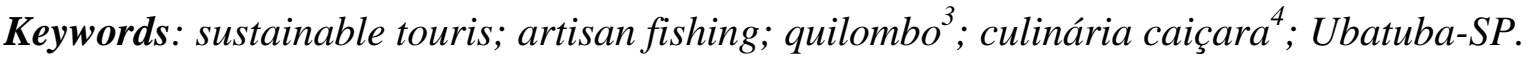

\section{Resumen}

La playa de Caçandoca, em Ubatuba, tiene uma comunidad de pesca artesanal que es también remanesciente de um "quilombo". Después de la apertura de rodovias permitiendo acceso al litoral norte de São Paulo, em los años setenta, la comunidade sufrió muchas pressiones de la especulación inmobiliaria para su desahucio o transferência, por causa de la belleza del lugar y sus possibilidades de uso turístico. Mas ella obtuvo el reconocimiento de su propriedade territorial, como "tierra de quilombo", y hoy busca mantener su identidade y su cultura material. Una parte importante de esa cultura es su culinaria de peces, investigada por el A. en entrevistas abiertas com antiguos moradores de Caçandoca. $Y$ hoy, proyectos comunitários y de gobierno ofrecen alternativas de aprovechamiento de esa cocina tradicional en uma actividad de turismo sustentable.

Palabras-clave: turismo sustentable; pesca artesanal; quilombo ${ }^{5}$ culinária caiçara; ${ }^{6}$; Ubatuba-SP.

\section{Introdução}

A Caçandoca, uma das belas praias de Ubatuba, litoral norte de São Paulo, ostenta uma notável peculiaridade: as terras de seu entorno constituem um quilombo remanescente, oficial e legalmente reconhecido depois de muita luta, onde uma população tipicamente caiçara vive da pesca e da agricultura, e passa nos últimos anos a vivenciar as dificuldades e oportunidades trazidas pelo turismo. A comunidade ali existente se insere em uma realidade mais ampla, reproduzida em grande parte do litoral brasileiro: a dos núcleos de pesca artesanal.

\footnotetext{
${ }^{3}$ Place where lived together ancient fugitive slaves.

${ }^{4}$ Coastland community's cookering.

5 Lugar de refugio y morada de antiguos esclavos fugitivos.

${ }^{6}$ Culinaria de comunidades del litoral.
} 
O universo da pesca artesanal se estende por milhares de quilômetros da costa brasileira, entremeado de cidades, praias, portos, marinas, condomínios fechados, paraísos turísticos, reservas ecológicas, aldeias indígenas, cada qual com seus costumes, tradições e peculiaridades. Como diz Diegues (1983, p. 2):

A atividade pesqueira deu origem a inúmeras culturas litorâneas regionais ligadas à pesca, entre as quais podem ser citadas a do jangadeiro, em todo o litoral nordestino, do Ceará até o sul da Bahia; a do caiçara no litoral entre o Rio de Janeiro e São Paulo, e o açoriano, no litoral de Santa Catarina e Rio Grande do Sul. Enquanto esses dois últimos tipos de pescadores estiveram também ligados à atividade agrícola, os primeiros dependiam quase que inteiramente da pesca costeira.

Basta se afastar um pouco dos grandes centros, para encontrar comunidades de homens e mulheres em uma vida simples e íntegra, vivendo há séculos em meio à natureza complexa e exuberante de nossa beira mar. É importante notar que muitas delas vivam conjuntamente da atividade da pesca e da agricultura, assim como comunidades indígenas anteriormente existentes. Nesse cenário, Beck (1989, apud Adams, 2000, p. 147), ao discutir o conceito de pescador artesanal, caracteriza as comunidades pescadoras-lavradoras mediante

[...] a relação entre a pesca de pequena escala (ou artesanal) e a agricultura de pequena escala (ou familiar, camponesa), 'sintetizada na dupla identidade auto-atribuída: lavradores e pescadores'. O lavrador domina o conhecimento da terra, dos ciclos anuais, das técnicas, dos períodos de chuva e seca e tem o controle do grupo familiar para o trabalho na roça e no engenho. O pescador é o que domina o conhecimento do mar e da pescaria. Esta articulação entre roça e pesca parece ter uma importância fundamental na organização da vida econômica, do universo simbólico e de toda a organização social do lavrador-pescador.

As raízes históricas de muitas dessas comunidades, bem como sua cultura material, são bastante remotas. Deve-se aos primeiros habitantes da terra o "descobrimento" da ictiofauna brasileira, que desde tempos remotos lhes garante a sobrevivência, e de quem os atuais brasileiros herdaram os inúmeros saberes e técnicas de obtenção e processamento. Capturados com anzóis, armadilhas, venenos, preparado moqueado, torrado, pilado, feito pirão, os peixes 
e frutos do mar nas comunidades caiçaras transmitem os saberes imemoriais, consagrados no ritual cotidiano da sobrevivência. As comunidades e culinárias litorâneas e ribeirinhas carregam a tradição indígena do peixe, em meio às heranças ancestrais de sua cultura material.

Hoje, entretanto, em que pessoas de muitas procedências praticam os mais variados tipos de pesca, é necessário conceituar melhor o que é pesca artesanal diante da modernização do setor. Além de seu caráter de menor escala, diante do avanço da pesca industrial com grandes barcos e muitas redes, deve-se levar em conta essa atividade pesqueira artesanal como parte de toda uma cultura e um modo de vida em que a produção se vincula às crenças, valores e tradições da comunidade. Como diz Sganzerla (2008, p. 28),

[...] com os esforços pela modernização do setor pesqueiro, na década de 1960, foi necessário rever a pesca no contexto nacional, a fim de integrar a atividade na divisão social do trabalho de acordo com as normas previstas pela Organização Internacional do Trabalho (OIT) e dentro do quadro de acumulação de capital do país [...]. A partir daí, os estudos na área passaram a abordar suas formas de produção especificas, seus consequentes 'modos e normas de utilização da natureza, representações do trabalho e meio produtivo', distinguindo, na atividade pesqueira, diferentes tipos de pescadores conforme suas formas de produção.

Assim, diversos órgãos governamentais como o Ministério da Pesca vêm crescentemente manifestando atenção aos pescadores artesanais, que por sua vez procuram em muitos lugares se organizar em "associações" para ser melhor ouvidos; isso, entretanto, se choca com o estímulo igualmente conferido à pesca industrial, que compete de maneira extremamente desigual com os primeiros.

Antonio Carlos Diegues, em Pesca e marginalização no litoral paulista (1971) e Pescadores, camponeses e trabalhadores do mar (1983), usando um enfoque da antropologia econômica, analisou as relações conflituosas entre a pesca artesanal e a pesca empresarial em termos de modo de produção, enfocando os aspectos sócio-políticos da emergência das empresas pesqueiras no país. Um dos aspectos importantes do trabalho é a análise da articulação e dependência da pesca artesanal em relação à empresarial, a desorganização da pesca artesanal, principalmente entre os pescadores do litoral norte do Estado de São Paulo. (DIEGUES, 1998, p. 6) 
Como se verá, a concorrência industrial não só é muito poderosa, como leva às vezes até mesmo ao abandono da atividade pesqueira por parte de muitos caiçaras. Mas antes é necessário caracterizar as comunidades que, como a Caçandoca, pertencem ao mundo litorâneo de Ubatuba. Mundo em que está presente o "caiçara" (nome que em tupi-guarani designa os cercos de madeira que os indígenas e depois os pescadores atuais usam na água para aprisionar peixes na subida da maré).

Essa porção do litoral paulista, chamada de "litoral norte" e que inclui os municípios de São Sebastião, Caraguatatuba e Ubatuba, além do município fronteiro da Ilhabela, ficou durante séculos à margem das atividades produtivas dominantes no Estado, que tiveram em Santos o seu escoamento exterior e sua dinâmica mercantil. Ubatuba, em particular, até o início dos anos 50, ficou extremamente frágil do ponto de vista econômico, a ponto de França (1951, p. 11), dizer: "Pode-se pensar que a melancólica decadência de Ubatuba a configure como uma cidade triste, estagnada e inexpressiva."

Esse mesmo autor informa que, por outro lado, muitas dificuldades se interpuseram à comunicação e aos deslocamentos dentro do município, mercê do fato de que entre as suas 74 praias, existem costeiras de pedra que dificultam muito o acesso. Assim, os agrupamentos de casas de pescadores existentes em muitas das praias ficaram bastante isolados uns dos outros até à construção da estrada Caraguatatuba - Ubatuba (1950) e principalmente até a da Rodovia Rio-Santos (1975). Esse isolamento poderia permitir aplicar a esses agrupamentos a denominação característica de "bairro", no sentido usado por Maria Isaura Pereira de Queiroz, para quem "o bairro apresenta as formas mais elementares de sociabilidade da vida rústica" (QUEIROZ, 1973, p. 13).

Os próprios caiçaras de Ubatuba usam às vezes a denominação de "bairros" para suas unidades, normalmente associadas a acidentes geográficos, como "do Corcovado" ou "do Rio Escuro". Entretanto, após a criação das estradas e a chegada rápida de turistas e veranistas, essa caracterização ficou difícil de ser aplicada. Como diz Setti (1985, p. 5):

Certos bairros e certas praias abrigam uma extraordinária mescla de ocupação, onde convivem simultaneamente caiçaras e paulistanos de classe 
média [...]. Dada a interferência de indivíduos portadores de cultura e comportamentos diferentes, provindos também de diferentes estratos sociais, torna-se difícil encaixar os bairros ubatubanos atuais aos modelos ideais de agrupamento verificados por Maria Isaura Pereira de Queiroz e Antonio Candido em regiões do interior paulista.

A mesma autora reconhece, porém, que ainda permanecem em Ubatuba áreas em que o caiçara é ocupante único ou mais presente, particularmente nas praias ou partes do sertão junto à Serra ainda não atingidas por estradas de rodagem ou ruas em que possam passar automóveis. Alguns destes são: a Praia do Bonete, o sertão da Quina, o Prumirim e a Puruba, a praia do Almada, a Justa, a Cabeçuda, a Joatinga, entre outras; e, nessa condição exatamente a Caçandoca ${ }^{7}$.

Nestes lugares, continua-se a utilizar o termo comunidade para os agrupamentos humanos de pescadores, seguindo uma tradição que já Mussolini (1952) utilizava, justificando: “A pesca representa, em geral, uma forma de organização do trabalho e produção que transcende os limites meramente familiares para se transformar em atividade comunitária." (MUSSOLINI, 1953, p. 89).

Este artigo trata da culinária de pescados na comunidade residente de Caçandoca e as possibilidades de aproveitamento dessa cultura tradicional no âmbito do turismo sustentável, analisando, de que formas essa comunidade conseguiu o reconhecimento da terra de quilombo como propriedade territorial e a manutenção de sua identidade e cultura material. $\mathrm{Na}$ forma de pesquisa exploratória, de caráter qualitativo, se apóia em fontes impressas e eletrônicas, e em visitas "in loco" e entrevistas com residentes locais, realizadas em outubro de 2010. Os entrevistados se apresentaram voluntariamente mediante contato inicial com a liderança da comunidade.

Inicia-se este artigo, abordando as mudanças na natureza e nas tradições ao lado da luta quilombola na região a partir da década de 1970. Em seguida são analisadas as características da culinária local e suas influências, e d os projetos desenvolvidos pela comunidade e pelo governo sobrealternativas dessa culinária tradicional para o turismo sustentável. Ao final,

\footnotetext{
${ }^{7}$ No momento da publicação deste artigo possivelmente algumas das localidades citadas já estejam recebendo acesso de automóveis, dada a velocidade da ocupação turística.
} 
ressalta a necessidade de serem tomadas medidas de preservação da cultura e, em particular, da culinária tradicional em comunidades litorâneas, frente ao turismo predatório.

\section{Natureza, Tradição e Luta Quilombola}

A região onde vivem os moradores da Caçandoca pertence ao território que, de uma maneira mais geral, se estende desde o norte do Paraná até o sul do Rio de Janeiro, chamado "caiçara". No litoral norte de são Paulo, ela adquire características fisiográficas privilegiadas, pois ali a Serra do Mar se mistura com a costa, com seus esporões formando ilhas e encostas. O bioma serrano se confunde com o praiano, proporcionando recursos de pesca, caça, coleta e agricultura muito ricos, além de paisagens de deslumbrante beleza natural.

A entrada para a Caçandoca se faz pela rodovia Rio Santos, BR-101, no sul de Ubatuba. Como diz uma crônica de jornal:

A cada quilômetro que nos distanciamos da BR-101, km 78, bairro da Maranduba, podemos nos dar ao luxo de sermos transportados à história viva do Remanescente do Quilombo de Caçandoca, com condução própria ou fazendo uma fantástica caminhada.

Nos três quilômetros de percurso nos deparamos com a beleza nobre da Mata Atlântica, onde o colorido de plantas nativas funde-se com a beleza do azul do mar. Surpreendentemente, alguns bois e cavalos desfilam pela estrada. Aos poucos, percebe-se um imenso pasto que limita-se com as areias da praia. Bebês bezerros acompanhados por suas genitoras, cabritos, galinha d'angola, a coruja que choca seus filhotes, são herança da antiga fazenda Caçandoca.

A praia-fazenda enfeita sua orla com coqueiros e árvores centenárias. A história da luta pela liberdade da alma e pelo direito de herança à terra, é registrada em cada rosto dos descendentes quilombolas, que incansavelmente lutam, através de documentos, pela legalização do que vem a ser o primeiro remanescente de quilombo do Litoral Norte. (OLIVEIRA, 2001, s.p.)

A trajetória dessa comunidade teve início quando José Antunes de Sá, fazendeiro de origem portuguesa, comprou as terras que formaram a fazenda Caçandoca. Originalmente ela possuía um engenho de cana, para fabrico de aguardente, além de produzir café. Em 1881, a fazenda foi desmembrada entre filhos e netos do antigo proprietário, mas nos lotes em que estes não 
permaneceram, vários herdeiros bastardos, filhos de mãe escrava, ficaram como posseiros. Com o tempo, a sede da fazenda foi abandonada, e os ex-escravos ou bastardos foram ficando nas terras: eles deram origem às 54 famílias que hoje formam o Quilombo, com um pouco mais de mil remanescentes. Como diz Vieira (2008, s.p.)

A maioria das casas da comunidade, feitas de parede de taipa e cobertura de sapê, tem cama de bambu e colchão de tábua. Os utensílios domésticos são de barro e ferro. O pilão ainda serve para amassar o café. 'A linha de pesca era tirada do tucum do coco e as cordas grossas para puxar a rede eram de cipó', descreve Antônio dos Santos, presidente da Associação dos Remanescentes da Comunidade do Quilombo da Caçandoca. E acrescenta: 'Os quilombolas defendem o território e os costumes de seus ancestrais'. Os costumes religiosos no quilombo da Caçandoca estão sendo resgatados com a participação da comunidade na procissão marítima da Festa do Divino. Outras festas comemoradas são de São Benedito (santo negro), São João, Santo Antônio e São Pedro (padroeiro dos pescadores).' Até os anos 60, tinha festa o ano todo na comunidade. Começava com a cantoria de Reis no natal, passando pelo primeiro dia do ano e no dia 7 de janeiro, iniciava a folia do Divino. Este período era sagrado. Os quilombolas deixavam de fazer mutirão - trabalhar junto numa mesma roça - para homenagear os santos. A reza durava nove noites e na última acontecia a festa com as danças que iam até o dia clarear', afirma Antônio. As danças eram o bate pé, ciranda, moçambique e dança do chapéu. 'Tinha fogueira, doce de mamão e abóbora e mandioca assada'.

Algumas mulheres da Caçandoca fazem artesanato para vender na cidade. São colchas e panos de enfeite feitos com retalhos, a palha da banana se transforma em balaios e descansos de panela, as cortinas são enfeitadas com conchas e a bolsa é produzida com 'anel' de latinha. A arte é ensinada de mãe para filha.

As vicissitudes do povo da Caçandoca se tornaram graves a partir dos anos de 1970, com o "boom" turístico e a especulação imobiliária. $\mathrm{Na}$ época, houve um despejo muito violento, desencadeado criminosamente por um grupo de grileiros. Casas foram derrubadas, animais foram mortos e as plantações foram queimadas. Gabriela dos Santos, filha do líder da comunidade, comenta em entrevista a expulsão e o despejo forçado de muitos amigos e parentes:

Levaram as coisas e as pessoas [...]. Ela mesma (aponta para outra mulher da comunidade) a sogra dela, saiu tudo num caminhão baú, não é Cidinha? Saíram num caminhão baú, soltaram logo ali na estrada, depois da cachoeira. Eles queimaram a casa deles com tudo, com a casa de farinha, os cachorros, 
os patos, as galinhas. Houve morte. E ainda com tudo isso, tem a perseguição: eu e meu marido estamos ameaçados de morte até hoje porque nós tivemos a ideia de voltar para aqui.

O despejo fez com que os quilombolas se dispersassem e só viessem a se agregar de novo no fim dos anos 1980 e início dos 1990. A sua luta continuou, pois os interesses imobiliários na área continuaram a crescer. Os habitantes dos 890 hectares que formam o território quilombola quase foram despejados em abril de 2005, por força de uma ação movida na Justiça pela imobiliária Urbanizadora Continental. A empresa queria aproveitar as praias de lá para construir um condomínio fechado de luxo.

A resistência a essa invasão se consolidou exatamente dentro da luta de Caçandoca para ser reconhecida como remanescente de quilombo, o que constitui um elemento a mais nas lutas sociais brasileiras.

A partir da Constituição brasileira de 1988, o quilombo adquire uma significação atualizada, ao ser inscrito no art. 68 do Ato das Disposições Constitucionais Transitórias (ADCT) para conferir direitos territoriais aos remanescentes de quilombos que estejam ocupando suas terras, sendo-lhes garantida a titulação definitiva pelo Estado brasileiro. (CARRIL, 1997, p. 23)

Assim, quilombo ou remanescente de quilombo, termos usados para conferir direitos territoriais, constituem uma inovação do ponto de vista político do direito. Além disso, a legislação e os que lutam por sua aplicação recorrem também à antropologia para qualificar os remanescentes de quilombos como tais, pois:

O texto constitucional não evoca apenas uma 'identidade histórica' que pode ser assumida e acionada na forma da lei. Segundo o texto, é preciso, sobretudo, que esses sujeitos históricos presumíveis existam no presente e tenham como condição básica o fato de ocupar uma terra que, por direito, deverá ser em seu nome titulada (como reza o art. 68 do ADCT). Assim, qualquer invocação do passado deve corresponder a uma forma atual de existência capaz de realizar-se a partir de outros sistemas de relações que marcam seu lugar num universo social determinado. (CARRIL, 1997, p, 23) 
A existência efetiva como comunidade, praticando a pesca e a agricultura, possibilitou aos habitantes da Caçandoca comprovar sua condição de remanescente quilombola, dentro de uma efetiva mobilização dos seus habitantes. Gabriela conta como os moradores da Caçandoca resolveram se mobilizar, buscando também apoio político para conseguir a vitória do reconhecimento.

Aí meu marido falou com um vereador e ele falou assim: 'Vocês tem algum documento que prova que é de vocês?' -'Temos'. Aí ele pegou os documentos e levou pra Doutora Maria Lucia Frange, deputada que era do PT, e ela nos encaminhou para outro deputado que na época era assessor do Paulo Teixeira, hoje ele é um deputado, o Simão Pedro que acompanha a gente. O Paulo Teixeira encaminhou a gente pra Governo do Estado, pro ITESP (Instituto de Terras do Estado de São Paulo). Eles fizeram um trabalho de dois anos de reconhecimento da área como quilombola, ficamos com o ITESP até quando o Lula entrou. Quando ele estava de candidato, eu pedi apoio para ele e ele falou que se ganhasse podia contar com o apoio dele. Ele ganhou as eleições e a primeira comunidade que ele viu foi a nossa, e dia $1^{\circ}$ de junho de 2005 , ele deu nosso reconhecimento.

Depois de grande mobilização de entidades e movimentos sociais como os dos negros, o Tribunal de Justiça de São Paulo suspendeu, naquele dia, a liminar de reintegração de posse da Continental sobre a área de Caçandoca. No mesmo dia, o Incra reconheceu as terras como pertencentes aos quilombolas, e abriu caminho para o processo que levou ao reconhecimento e à titulação como terra do quilombo, em setembro de 2006 (SAMPAIO, 2006). E Gabriela continua:

Foi no dia de Cosme e Damião. Aí o pessoal falou: 'está passando na televisão o Lula falando da comunidade'. E aí a gente fez uma festa. Aí o Governo federal veio, está trabalhando com a gente. O Incra contratou funcionários e fizeram novamente o reconhecimento e agora estão os dois governos, o estadual e o federal. A gente discutiu muito com os assentados a nossa aposentadoria, o Fome Zero, comida para os quilombolas, comida para os assentamentos, nós conquistamos. Luz que não tinha conquistamos. A Saúde é que não chegou ainda pra nós. 


\section{Características Culinárias e Influências}

A demarcação das terras e o reconhecimento dos caiçaras da Caçandoca como remanescentes quilombolas começaram por facilitar a vida da comunidade. Mas há ainda um longo caminho para ser feito, ou refeito, diante do fato de que os recursos de sua cozinha cotidiana estão sendo submetidos a diversos fatores negativos, tanto com as dificuldades crescentes da pesca artesanal quanto com a mudança de função de uma parte dos trabalhadores, principalmente os mais jovens, atraídos pelos novos empregos que a ocupação turística das praias que rodeiam a Caçandoca oferecem. E os ingredientes da cozinha são todos eles tradicionais.

A culinária caiçara foi desenvolvida com base nos ingredientes frescos oriundos da pesca e da serra. Os sambaquis são evidências arqueológicas que indicam que os índios genuinamente brasileiros já tinham como hábito se alimentar de pescados e crustáceos. Os caiçaras, por sua vez, obtinham da mata, além da caça, as raízes e os vegetais. [...] Nos lugares que não havia eletricidade e nem equipamentos para gelar os peixes a solução para mantêlos, em boas condições de consumo e por mais tempo, era salgá-los e secálos. Assim, os pescados eram mantidos sobre o fogão à lenha para serem secos, mas havia uma série de cuidados específicos em torno deste procedimento. [...] a lenha, por exemplo, teria que ser específica e os pescados eram constantemente vigiados para que não pousasse sobre eles moscas varejeiras. Também os peixes deveriam ser gordos para que pudessem ser submetidos a esta técnica, pois o que os cozinhava era a sua própria gordura.

A mandioca é uma iguaria de muito valor na culinária caiçara. Além do uso desta raiz no cotidiano alimentar, apresentada frita, assada ou cozida, a farinha dessa tuberosa também é bastante aplicada à produção dos pratos servidos nessas comunidades. O milho e o arroz também fazem parte da alimentação dos caiçaras que assim como a mandioca, são consumidos como farinha ou no preparo de pirões ou pães. (LUDERER, 2010, s.p.)

Ao se fazer entrevistas com o pessoal da comunidade da Caçandoca, os elementos culinários ligados à pesca aparecem com muito realce. Perguntada sobre a maneira de fazer e acompanhar o pirão de peixe, a jovem filha do líder da comunidade, Gabriela, enfatiza:

Quem quiser feijão, põe feijão. Tem gente que não gosta. A gente faz o pirão pra gente que vem de fora, mas pra gente mesmo a gente cozinha a banana e amassa a banana no prato, põe a farinha e já faz o pirão mesmo ali. Amassa, põe o caldo a farinha e já faz na hora o pirão. 
Filho mais velho da comunidade, já com 81 anos seu João tem 19 bisnetos e conta sobre a história gastronômica do território do quilombo. Vivia-se da pesca e da roça locais, conta em entrevista:

[...] tinha a farinha, a mandioca, tinha o feijão, tinha o milho, tinha café, tinha cana pra fazer a garapa e daquela garapa fazia-se o café, não tinha esse negócio de açúcar, era o café socado no pilão, fazia o pó, moía a cana naquele engenho virado a mão. Fazia a garapa pra fazer o café. A mandioca plantava nesses morros, sacos e mais sacos daqueles pedacinhos das ramas da mandioca. (...) Amanhã era o dia de plantar aquela roça. $\mathrm{O}$ senhor já saía avisando a vizinhança toda aqui, tinha mais de quarenta casas. (...) Quando chegava no outro dia, quando começava a clarear, estava cheio de gente. O café já estava pronto. Mandioca doce cozida pra comer com café. Polenta, naquele tempo a gente chamava de angu. E aquele fubá era socado no pilão com água. A gente assava uma sardinha no fogo. Pegava o milho verdinho, socava bem socadinho tirava aquele farelo fora, fazia aquele mingauzinho bem fininho pra dar pras crianças. Nós plantávamos aquela roça pra fazer farinha: para isso, era a roda virada a mão: quando chegava no outro dia, era muita farinha, quatro, cinco, seis sacos e trinta, quarenta quilos cada saco.

Segundo os depoimentos, a produção de farinha era doméstica e artesanal, e cada casa possuía as ferramentas necessárias. O forno era de cobre e a lenha. A banana e a pescaria eram importantes fontes de subsistência. A captura de camarão e tainha, esta farta durante o mês de julho, era feita com "arrastão da praia”, ou "picaré". "O arrasto é de dez, onze pessoas". Sem anzol, "era peixe pra todo lado": corvina, pescado, cação. As ovas de tainha eram dispostas ao sol, para secar, e "a gema ficava amarelinha".

A técnica no forno é assim descrita pelo seu João, morador do quilombo: no forno tem a brasa por cima e aquele lugar de colocar a lenha, aí tirava a lenha, a brasa e tudo e só com aquela quentura que ficava no fundo, a gente punha as ovas ali, tapava a boca do forno e com aquele calor ficava cozidinho.

A força da agricultura se afirmava pelo respeito à sazonalidade dos roçados: Cada qual tinha o seu quadro de roça. Quando era tempo de plantar milho era milho. Quando era feijão, 
feijão dava de montão. Atrás de uma das casas rústicas do povoado central do Quilombo, um pouco maior para servir de "sede" da associação civil que o povo organizou, encontra-se um enorme fogão a lenha, em que duas senhoras preparam refeições coletivas, em geral de pescados. Laura, uma senhora de seus 45 anos, nascida ali na Caçandoca, demonstra seus dotes culinários, antigas sabedorias da comunidade. Enquanto frita uma tainha, começa uma explanação sobre mariscos:

Coloca o marisco na panela e quando está começando a abrir, coloca o arroz. O arroz cozinha dentro do marisco. (...) Aí coloco o tempero, agora já adere o tempero. Cebolinha, tomate, tudo o que a gente achar pela frente. Já os mexilhões, eu gosto de comer na moda em que minha mãe fazia. Ou cozinha ele e vai tirando a casca e vai comendo, ou ao contrário, você tira a casca, joga ele na cebola e fica mais saboroso. Refoga sem pimentão sem nada, só cebola curtinha. Quando vêem visitas, aí a gente faz o vinagrete, já é diferente. Faz com arroz. Pra gente mesmo a gente come à nossa moda. Pode ser também o marisco assado. Teve uns universitários que vieram aqui no final do ano passado e usaram esta chapa aqui, e não havia nem como a gente fazer o molho. Aí comeram marisco assado, e gostaram... O tempero dos nossos antepassados já era assim: Cozinhavam os mariscos no fogo, tiravam, colocavam a panela no chão, colocava uma cuia de farinha e comia com arroz e feijão, era a nossa mistura.

Quanto aos peixes como a sardinha, a tainha e a corvina, ela aduz, já revelando uma inevitável preocupação com as agruras de um cotidiano atual de menos fartura:

O peixe era frito mais na gordura de porco, não existia quase outro óleo, ou a gente comia ele assado na brasa. Era um tempo que a gente tinha mais saúde, a gente era mais natural. Agora não, a gente fica comendo essas coisas [...] muita química [...] e todo mundo vive doente porque fica comendo besteira $[\ldots]$.

E logo Laura deriva para a lembrança de um passado talvez mítico, mas sempre marcante:

Nossa comida era assim: Vinham da costeira aqueles balaios de mariscos e saquaritás e colocavam ali, e já cortavam e iam tirando os pedaços. Saquaritá é bom: puxa a pelinha dele e sai inteirinho. Tira o fel, que tem na ponta, no fígado dele e fica muito saboroso. Ele não é uma concha fechada, ele é abertinho. É como se fosse um caracolzinho, anda como um caracol. 
A manifestação de antigas sabedorias é sempre valorizada pelos entrevistados.

Particularmente o conhecimento de plantas medicinais:

Na casa da gente tinha plantado tudo que era tipo de medicamento, aí seis horas da manhã a gente saia e colhia, deixava secar e quando sentia alguma coisa fazia o chá. Ficava em cima dos fumeiros, pra pegar só a caloria, como se fosse uma defumação. A gente tomava aquele chá e ficava curada. Quando via que não tinha outra solução, levava pras benzedeiras e fazia os benzimentos na gente [...] e assim a gente vivia. Agora não. Dá uma dor de barriga, anda três quilômetros pra ir ao doutor.

$\mathrm{Na}$ entrevista, o Sr. João é quem começa a se queixar mais do fato de que a concorrência de grandes barcos pesqueiros torna cada vez mais difícil a pesca artesanal.

Quando eu pegava o barco, pro Sul, ia até a divisa com o Uruguai. Pesquei muito atum. Agora o atum falhou muito. No tempo que eu fazia a pesca a gente trazia pra terra era só atum. Hoje é mais aquele cação, o anequim. Mas ele é muito bravo". E o camarão, também estão ficando mais difícil. A maioria dos pescadores daqui pesca é com barco, mas tem uns que pescam com rede, com a marisqueira. Lá pro lado da Maranduba já é com barco. O pessoal sai daqui e vai pescar em outro lugar, agora o peixe aqui falhou muito. Já que a pesca não dá, eles vão trabalhar de pedreiro, de pintor, aqui por perto.

Perguntado sobre se ainda há peixe suficiente para se comer todo dia, o Sr. João afirma que sim, embora se coma também muita galinha. Mas nesse momento é atalhado pela Gabriela, que fala de outros peixes ainda disponíveis, como o timbale e o tanagaiú.

O tanagaiú é grande e é bom para fazer ensopado. Tem outros peixes que agente faz ensopado, como corvina e bagre. O bagre dá também pra fritar, mas tem que saber, é que nem a lula. $O$ espada também você frita, mas o ensopado também é bom. E o tempero que a gente põe no ensopado, além de cebola e alho, é o coentro, cheiro-verde, tomate. O que eu ia fazer agora eu ia colocar só coentro e cebola. A banana com peixe e o coentro e a cebola. Tem um coentro grande que dá ai no mato.

Mas a verdade é que outas influências rapidamente se colocam sobre a culinária tradicional.

Nas proximidades da Caçandoca, na vila da Maranduba e no lado oposto, estabelecimentos 
comerciais trazidos pelo turismo vendem alimentos industrializados, etc. Os caiçaras que vão trabalhar nos muitos serviços demandados pelos turistas passam a consumir também esses alimentos, ainda mais que os insumos tradicionais escasseiam, entre outras coisas porque menos braços trabalham neles. Foi possível observar a presença até mesmo pacotes de salgadinhos Chips em umas poucas casas da comunidade.

A maneira de preparar o peixe continua sendo mais tradicional, como se viu. Mas os outros ingredientes, como a galinha, estão sendo feitos por muitos caiçaras das maneiras "urbanas" que estão chegando, e influenciando a cozinha caiçara.

\section{Turismo e Projetos}

Assim que as estradas e os automóveis começaram a chegar às praias de Ubatuba, Caraguatatuba e São Sebastião, o início do contato do turista com as comunidades caiçaras ainda tinha um elemento de troca interessante, uma fruição do recém-chegado sobre aquele mundo ainda "natural" em que a gastronomia simples do pescador e o frescor do pescado ainda eram elemento básico de atração turística. Como diz Luderer (2011, p. 13):

Da praia assistia-se a chegada de pescadores que em seus pequenos barcos coloridos vinham do mar, carregados de peixes. Também se via os profissionais do mar jogando estrategicamente suas tarrafas quando os botos indicavam a chegada de cardumes de tainhas. Ainda era possível assistir os saltos das sardinhas, pescado bastante popular na região. A culinária, e o deleite da gula, acontecia depois de apreciar tal cenário. Os peixes frescos, que chegavam pelas mãos dos pescadores, seriam preparados por seus familiares ou mesmo por outras pessoas da comunidade. Nas pequenas construções de madeira a beira mar, os visitantes acomodavam-se em bancos coletivos de madeira, que ficavam em torno de mesas retangulares, mal pintadas e fincadas na areia. Os pratos, para que as pessoas se servissem das iguarias preparadas, eram de plástico e coloridos. A travessa que apoiava o peixe e os acompanhamentos eram grandes, pois as porções eram fartas para serem compartilhadas. [...] Por fim, as vestimentas dos glutões, para saborear tamanha iguaria, eram as suas próprias roupas de banho.

Nesse quadro, a culinária tradicional caiçara se revelava um ponto essencial. Mas o que aconteceu e está acontecendo nessas mesmas praias em que os automóveis chegaram? A 
rapidez da especulação imobiliária e a mobilização massiva de turistas expulsam os caiçaras de suas casas, as vilas são engolidas por novos loteamentos e/ou casas e condomínios de luxo, muitos deles fechados e dificultando o acesso à praia. Nos novos arruamentos desses bairros praianos, restaurantes, bares e padarias rotinizam a comida; e embora se mantenham nesses estabelecimentos uns poucos pratos tradicionais, eles são substituídos por uma culinária que, quando não é simplesmente urbana e descaracterizada, é no máximo "mestiça", como diz a mesma Luderer (2011, p. 1).

Ora, é possível levar um turismo para a Caçandoca, ou para algumas das poucas praias ainda não atingidas por automóveis, sem manter ou recuperar a culinária caiçara tradicional? Isso pode ser debatido frente aos novos projetos turísticos que se estão desenhando para essa área e outras similares.

A propósito, em artigo de Correia, Costa e Balbino (2007), destaca-se uma proposta de atividades sustentáveis para outro quilombo, o de Monte Alegre, no município de Cachoeiro do Itapemirim. Naquele caso, há uma intervenção concreta de um grupo de alunos do Centro Universitário São Camilo, do mesmo estado do Espírito Santo, no sentido de promover junto à comunidade o seu desenvolvimento em padrões de sustentabilidade, além de ações objetivas no sentido da educação de crianças e jovens, o programa denominado Passos da Liberdade inclui o favorecimento de atividades geradoras de renda, entre eles o turismo exercido de uma maneira controlada e sustentável.

As visitas turísticas à comunidade são administradas pelo Instituto de Ecoturismo e Meio Ambiente Bicho do Mato, uma ONG formada por autóctones, em sua maioria universitários bolsistas. Em 2006, com o início do Programa, a comunidade recebeu 239 turistas. No primeiro semestre deste ano, 600 pessoas visitaram Monte Alegre. A previsão é de que até o fim deste ano a Comunidade Quilombola de Monte Alegre receba 1.200 turistas, a maioria estudantes de escolas públicas e privadas, do ensino fundamental à universidade, professores participantes de cursos de História da África, grupos de profissionais liberais em busca de mais contato com a natureza, na trilha ecológica da Flona de Pacotuba e da cultura e história afro-brasileira. Os turistas visitam pequenos empreendimentos rurais, a trilha ecológica do Escravo Adão na Flona de Pacotuba, assistem a apresentações culturais, [...] ouvem a descrição da história oral de Monte Alegre e degustam a saborosa gastronomia rural com pratos típicos da cozinha afrobrasileira. (CORREIA; COSTA; BALBINO, 2007, p. 46) 
Além dessas experiências mais distantes, no próprio entorno da Caçandoca há um projeto recente de turismo sustentável. Várias praias fazem parte do complexo praiano junto à área do quilombo, como a do Saco das Bananas, a Barra da Lagoa, a do Saco da Raposa, a do Pulso, e, bem próxima dentro das terras do quilombo, a Caçandoquinha, em que um projeto comunitário apresenta algumas possibilidades.

O acesso à pequena praia se dá por trilha a partir do canto direito da Praia da Caçandoca, leva-se somente 5 minutos de caminhada. Pode-se fazer pelo outro lado da costa também, saindo da praia da Lagoa na Tabatinga, leva-se aproximadamente 2 horas de caminhada intensa, de nível médio para difícil.

Não há ainda estrutura turística, apesar de suas atrações. É ainda uma praia selvagem, com sua natureza preservada em função do difícil acesso ao local. É freqüentada, normalmente, por pescadores que moram na região. (...) A prática da pesca e do mergulho são boas opções. (PROJETO SALVE CAÇANDOQUINHA, 2012, s.p.)

A Vila dos Pescadores da pequena praia tem cerca de 150 habitantes, dos quais os homens se dedicam à pesca e as mulheres ao artesanato local. Verdadeiro santuário natural como a Caçandoca, ela também sente a ameaça do turismo predatório e já começa a lutar pela preservação de seus valores. Como explica o boletim "Salve Caçandoquinha", acima citado:

Em 2011 a Cooperativa de Comunicação dos alunos da escola Comuniquese (COPERCOM) se uniu à Associação dos Pescadores para ajudá-los para a defesa do lugar, propondo uma Campanha de Comunicação para o Resgate da cultura local e pela preservação ambiental da Vila de Pescadores de Caçandoquinha. Passou-se a transmitir conceitos sobre o meio ambiente, ecossistemas, preservação ambiental e história local para que crianças e adolescentes monitorem e guiem visitas de turistas à comunidade." Além disso, desenvolveram-se atividades de artesanato e profissionalização: aulas sobre técnicas de desenvolvimento de matérias-primas e composição de acessórios e peças de decoração em artesanato sustentável, utilizando couro e peixe, bordado, fuxico, barro e outros materiais. As mulheres da comunidade participam de oficinas de artesanato e desenvolvem objetos em couro de peixe. O material é retirado da própria comunidade e os processos de curtimento e tingimento são ecologicamente corretos. (PROJETO SALVE CAÇANDOQUINHA, 2012, s.p.) 
A ação dos pescadores da Caçandoquinha funciona como um elemento de contágio para os da Caçandoca. A sua Associação também passoua pressionar para conseguir um projeto similar, no mesmo ano, mas seu caminho foi mais no sentido de solicitar ao governo, em particular ao ITESP, a elaboração do projeto. Este pretende a capacitação dos quilombolas para atender de modo adequado aos visitantes, como guias turísticos, e garantir uma alternativa de geração de renda. Além de revelar aos turistas as principais atrações da região como cachoeiras, praias, ilhas, trilhas e ruínas de antigas fazendas, os guias uniformizados promoverão ainda a conscientização ambiental. O projeto prevê ainda a construção de um restaurante no local.

A construção de um restaurante pode vir a ser uma fonte de renda importante, e manter a identidade tradicional da comunidade oferecendo pratos da sua rica cultura culinária. Há dificuldades de recrutamento e dedicação, pois como diz um relatório do próprio ITESP de 2006:

Os membros da Comunidade que hoje lá residem trabalham em atividades variadas, predominando os serviços domésticos em casas de veranistas no condomínio do Pulso e as atividades ligadas ao mar: pesca e coleta de mariscos, além da venda de banana. Dois deles trabalham como caseiros das casas de veraneio na Caçandoquinha e no Saco da Banana. As relações de trabalho entre membros da comunidade e as pessoas que têm interesses nas terras em questão torna delicada a situação dos primeiros frente ao processo de reconhecimento da sua condição e da identificação do seu território histórico. (ITESP, 2006, s.p.) Além disso, há falta de escolas, que seriam espaços importantes para trabalhos de formação. Havia uma escola de ensino primário na Caçandoca, desde as primeiras décadas do século XX até 1994. Como várias famílias se mudaram, a escola foi desativada sob a alegação de insuficiência de alunos. A Associação está reivindicando a reativação do estabelecimento, tanto para o ensino primário quanto para o ensino de jovens e adultos e cursos de treinamento e formação. Mas é todo um trabalho pela frente.

Esses e outros projetos turísticos que por ventura sejam desenvolvidos na região precisam ser discutidos frente à preservação da cultura local e às condições de sustentabilidade da localidade, de forma a não comprometer o desenvolvimento do turismo na mesma e a própria qualidade de vida da população residente. 


\section{Considerações Finais}

O empenho de manter a sua identidade e a posse de suas terras foi a marca das gerações da comunidade remanescente do Quilombo da Caçandoca. Marca que se assentou sobre a rotina de sobreviver da pesca e da agricultura, e no exercício do preparo dos ingredientes aí obtidos com a culinária tradicional herdada dos indígenas. Diante do desafio do turismo predatório, cada vez mais presente na região do litoral norte que cerca a comunidade, a organização de projetos de turismo sustentável tem se apresentado aos moradores e às autoridades interessadas na região, como o ITESP, como uma das possibilidades de integração e de desenvolvimento sustentável dos moradores, além de poder lhes permitir continuar exercendo a sua pesca artesanal tradicional e vivenciando sua cultura peculiar.

Naturalmente, projetos desse gênero exigem uma participação intensa das comunidades, como está começando a ocorrer em alguns lugares. A consciência de valorização e preservação de sua culinária tradicional, e da possibilidade dela se tornar um atrativo turístico, faz parte desse empenho, daí a importância de não se perder também o hábito da pesca e da elaboração culinária do pescado nos moldes tradicionais.

O turismo predatório é muito veloz e implacável. Por isso mesmo, há certa urgência de se tomar medidas no sentido da preservação dessas comunidades; daí a importância de se estudar e abordar, com os recursos do conhecimento científico e dos setores governamentais de apoio, as diversas Caçandocas que há por nosso litoral afora.

\section{Referências}

ADAMS, C. As populações caiçaras e o mito do bom selvagem: a necessidade de uma nova abordagem interdisciplinar. Revista de Antropologia, 2000, vol.43, n.1.

BECK, A. Lavradores e pescadores: uma contribuição à discussão do conceito de pescador artesanal. In: ENCONTRO DE CIÊNCIAS SOCIAIS E O MAR, 3, 1989. Coletânea de Trabalhos Apresentados, São Paulo: PPCAUB/IOUSP/F.FORD/UICN, 1989, p. 289-94.

CANDIDO, Antonio. Os parceiros do rio Bonito, São Paulo: Duas Cidades, 1971.

CARRIL, L. Terras de negros, herança de quilombos, São Paulo, Scipione, 1997.

CORREIA, W; COSTA, M. A. B.; BALBINO, W. Programa transdisciplinar para o desenvolvimento sustentável da comunidade quilombola de Monte Alegre. Revista Brasileira de Pesquisa em Turismo. v. 1, n. 2, p. 4-53, 2007. 
DIEGUES, A. C. Pescadores, camponeses e trabalhadores do mar. São Paulo: Ática, 1983.

DIEGUES, A. C. A sócio-antropologia das comunidades de pescadores marítimos no Brasil: uma síntese histórica, São Paulo: Centro de Culturas Marítimas - NUPAUB - Universidade de São Paulo, 1998.

FRANÇA, A. A Ilha de São Sebastião, estudo de geografia humana, São Paulo: FFLCHUSP/ Depto. de Geografia, 1951.

ITESP - Relatório técnico-científico sobre a comunidade do Quilombo da Caçandoca, município de Ubatuba / São Paulo, 2006. Disponível em: <http://www.itesp.sp.gov.br/br/info/acoes/rtc/RTC_ Cacandoca.pdf> Acesso em 29 set. 2011.

LUDERER, C. A. F. A projeção da cozinha caiçara na mídia impressa". In: XIII CONFERÊNCIA BRASILEIRA DOS ESTUDOS DA FOLKCOMUNICAÇÃO, São Paulo, PUC-SP, 2010.

MALDONADO, S. C. Pescadores do mar. São Paulo: Ática, 1986.

MUSSOLINI, G. Aspectos da cultura e da vida social no litoral brasileiro, Revista de Antropologia, 1953, Vol. 1, n. 2, p. 81-97.

OLIVEIRA, C. Caçandoca, elo histórico de nossas raízes. Jornal A Semana. Ubatuba, 26 maio, 2001. Disponível em <http://www2.uol.com.br/jornalasemana/edicao133/turismo.htm> Acesso em 27 set. 2010.

PIEVE, S. M. N., KUBO, R. R. e COELHO-DE-SOUZA, G. Pescadores da Lagoa Mirim: etnoecologia e resiliência, Brasília: MDA, 2009.

PROJETO SALVE CAÇANDOQUINHA. Disponível em: <http://salvecacandoquinha.wordpress. com/projeto-salve-cacandoquinha> Acesso em 27 set. 2011.

QUEIROZ, M. I. P. O campesinato brasileiro, Petrópolis: Vozes e São Paulo: Edusp, 1973.

SETTI, K. Ubatuba nos cantos das praias, São Paulo: Ática, 1985.

SAMPAIO, R. Quilombolas. Decreto presidencial devolve terras à comunidade de Caçandoca. Carta Maior. Disponível em: < http://www.cartamaior.com.br/templates/materiaImprimir.cfm?materia_id $=12438>$ Acesso em 11 ago. 2011.

SGANZERLA, E. Pescadores artesanais do Espírito Santo, Vitória: Esplendor, 2008.

VIEIRA, B. Caçandoca: Um 'refúgio' especial. Ubatubense. Disponível em <http://ubatubense.blogspot.com.br/2008/11/caandoca-um-refgio-especial.html> Acesso em 11 ago. 2011.

\section{Recebido em: 20/10/2011}

Aprovado em: 20/02/2012 (1 ${ }^{\mathrm{a}}$ versão) $02 / 03 / 2012$ ( $2^{\mathrm{a}}$ versão) 